\title{
Detection and Molecular Characterization of Peste Des Petits Ruminants Virus from Goat Flocks in Ambala, Haryana
}

\author{
Vandna Bhanot ${ }^{\text {** }}$, Aman Kumar ${ }^{2}$ and Naresh Jindal ${ }^{3}$ \\ ${ }^{1}$ ADIO, Disease Investigation Laboratory, LUVAS, Ambala, India \\ ${ }^{2} A B T$, LUVAS, Hisar, India \\ ${ }^{3}$ VPHE, LUVAS, Hisar, India \\ *Corresponding author
}

\section{A B S T R A C T}

\begin{tabular}{|l|}
\hline Ke y w o r d s \\
$\begin{array}{l}\text { Goat Flocks, } \\
\text { Peste des petits } \\
\text { ruminant (PPR) }\end{array}$ \\
\hline Article Info \\
\hline $\begin{array}{l}\text { Accepted: } \\
\text { 07 August } 2020 \\
\text { Available Online: } \\
\text { 10 September 2020 }\end{array}$ \\
\hline \hline
\end{tabular}

\section{Introduction}

Peste des petits ruminants (PPR), also known as'goat plague', is a viral disease of goats and sheep characterized by fever, sores in the mouth, diarrhea, pneumonia, and sometimes death. Etiologic agent has been classified as member of genus Morbillivirus of Family Paramyxoviridae. The disease is associated with high morbidity (100\%) and mortality (up to $90 \%$ ) (Abu-Elzein et al., 1990). PPR is also classified as transboundary animal disease (TAD) (Zahur et al., 2011). Animals of all ages are susceptible to the disease. The disease is characterized by pyrexia, dyspnoea, pneumonia, mucopurulent occulo-nasal discharge, erosive rhinitis, necrotic ulcers in mouth, on dental pad, tongue and lips. In early stages there is stomatitis followed by severe enteritis and diarrhoea (Taylor, 1984).

In India, PPR was first reported from Arasur, Villupuram district (Tamilnadu state) during 1987 (Shaila et al., 1989). PPR is now enzootic in India causing significant economic losses, and therefore, the infection is a major constraint for small animal production. Several RT-PCR assays have been developed for the rapid and specific detection of PPRV using different sets of 
primers targeting $\mathrm{F}, \mathrm{M}$ or $\mathrm{N}$ proteins (CouacyHymann et al., 2002 and Balamurugan et al., 2006). The present study was conducted to determine comparative efficacy of $\mathrm{F}$ and $\mathrm{N}$ gene based assays for molecular detection of PPR virus from clinical samples from goat flocks in Ambala district of Haryana.

\section{Materials and Methods}

\section{Collection of samples}

A total of 36 clinical samples including 18 blood and 18 nasal swabs were collected from goat flocks in and around Ambala, Haryana. These goats were suffering from fever, respiratory distress, coughing and nasal discharge suggestive of PPRV infection. A blood sample collected from an apparently healthy goat was used as negative control.

\section{Molecular detection of PPRV nucleic acid using RT-PCR}

The collected samples were tested for the presence of genomic RNA by the reverse transcription polymerase chain reaction (RTPCR) assay. Viral genomic RNA was extracted from collected samples using a commercial RNA extraction kit (Qiagen ${ }^{\circledR}$ RNeasy Universal Mini Kit) as per the manufacturer's instructions. RT-PCR was performed for the $\mathrm{N}$-gene and F-gene of PPRV using the QIAGEN® One-step RTPCR kit as per the manufacturer's instructions. Mastermix was prepared as per manufacturer's instructions containing $2 \mathrm{X}$
RT-PCR Buffer, RNA template, Enzyme Mix, RNAse Free Water and Primers with final concentration of $0.6 \mu \mathrm{M}$ (Table 2).

\section{Sequencing and phylogenetic analysis}

Subsequently, RT-PCR amplicons of PPRV positive samples were gel purified and sequenced using genetic analyser (3130XL) in the Department of Animal Biotechnology, LUVAS, Hisar. The nucleotide sequences of $447 \mathrm{bp}$ and $351 \mathrm{bp}$ amplicons amplified from $\mathrm{F}$ and $\mathrm{N}$ genes, respectively were aligned with corresponding sequences available in GenBank using Clustal W (Thompson et al., 1994). Phylogenetic analysis of $F$ and $N$ gene segments of PPRV was performed with the MEGA version 6 software. Phylogenetic analysis of the aligned sequences was performed by the Neighbor-joining method (Saitou and Nei, 1987). Bootstrap confidence intervals were calculated on 500 iterations.

\section{Results and Discussion}

Out of 36 clinical samples tested 28 samples were found positive by $\mathrm{N}$ gene-based primer set producing an expected amplicon of 351bp. $\mathrm{F}$ gene-based primers detected 23 samples positive for PPRV producing desired amplicon of size $447 \mathrm{bp}$. The causative agent of the disease PPR; is a member of genus morbillivirus in the family Paramyxoviridae (Barrett et al., 2005). It has a single strand negative sense RNA genome that encodes eight proteins in the order of 3'- N-P/C/V-MF-H-L-5' (Bailey et al., 2005).

Table.1

\begin{tabular}{|l|l|l|l|}
\hline Sr. no. & Primer & Primer sequence & Reference \\
\hline $\mathbf{1}$ & NP3 & 5'-GTC-TCG-GAA-ATC-GCC-TCA-CAG-ACT-3' & Couacy-Hymann \\
\cline { 2 - 4 } & NP4 & 5'-CCT-CCT-CCT-GGT-CCT-CCA-GAA-TCT-3' & et al., (2002) \\
\hline \multirow{2}{*}{$\mathbf{2}$} & F1b & 5'-AGTACAAAAGATTGCTGATCACAGT-3' & Dhar et al.,(2002) \\
\cline { 2 - 3 } & F2d & 5'-GGGTCTCGAAGGCTAGGCCCGAATA-3' & \\
\hline
\end{tabular}


Table.2 Cycling conditions used in one step RT PCR to amplify N and F gene

\begin{tabular}{|l|l|c|c|}
\hline S. No. & Step & Temperature & Time \\
\hline 1. & Reverse Transcription Step & 50 & $30 \mathrm{~min}(1$ cycle $)$ \\
\hline $\mathbf{2 .}$ & $\begin{array}{l}\text { Inactivates RT and activates } \\
\text { polymerase }\end{array}$ & 95 & $15 \mathrm{~min}(1$ cycle $)$ \\
\hline $\mathbf{3 .}$ & Denaturation & 94 & $1 \mathrm{~min}(35$ cycles $)$ \\
\hline $\mathbf{4 .}$ & Annealing & $\begin{array}{l}60(\mathrm{~N}-\text { gene }) \\
55(\mathrm{~F}-\mathrm{gene})\end{array}$ & $1 \mathrm{~min}(35$ cycles $)$ \\
\hline $\mathbf{5 .}$ & Extension & 72 & $1 \mathrm{~min}(35$ cycles $)$ \\
\hline 6. & Final Extension & 72 & 7 min $(1$ cycle $)$ \\
\hline
\end{tabular}

Fig.1
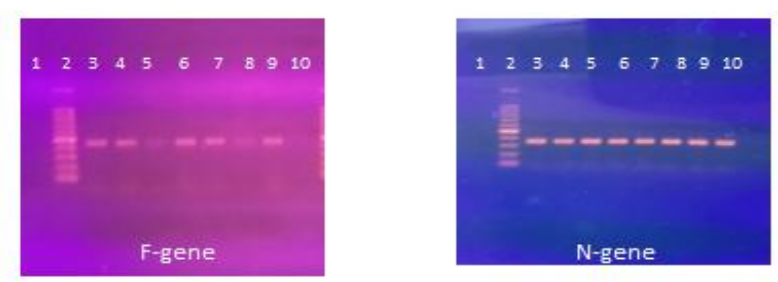

Agarose gel electrophoresis of amplified 447 bp product and 351 bp by PCR using F-gene and $\mathrm{N}$-gene specific primers for PPR virus; Lane 1 :Negative control, Lane 2:DNA marker, Lane3-10: Samplestested

Fig.2 Phylogenetic analysis of nucleotide sequence from the amplified product of $\mathrm{N}$ gene of PPRV with different lineages occurring worldwide

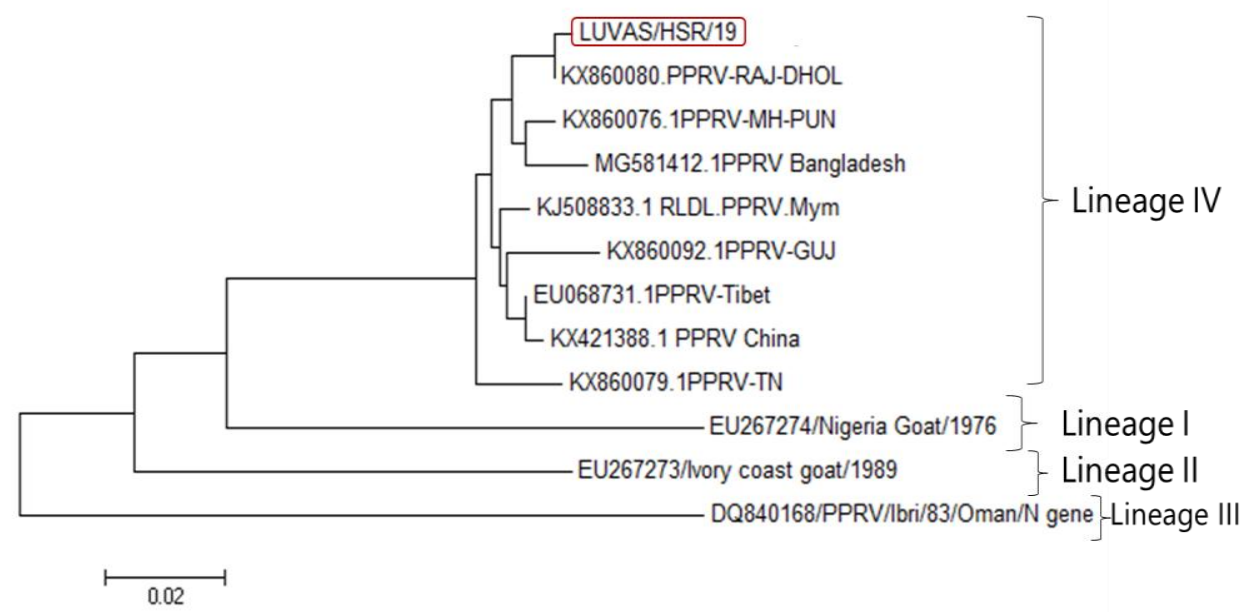


Fig.3 Phylogenetic analysis of nucleotide sequence from the amplified product of $\mathrm{F}$ gene of PPRV with different global isolates

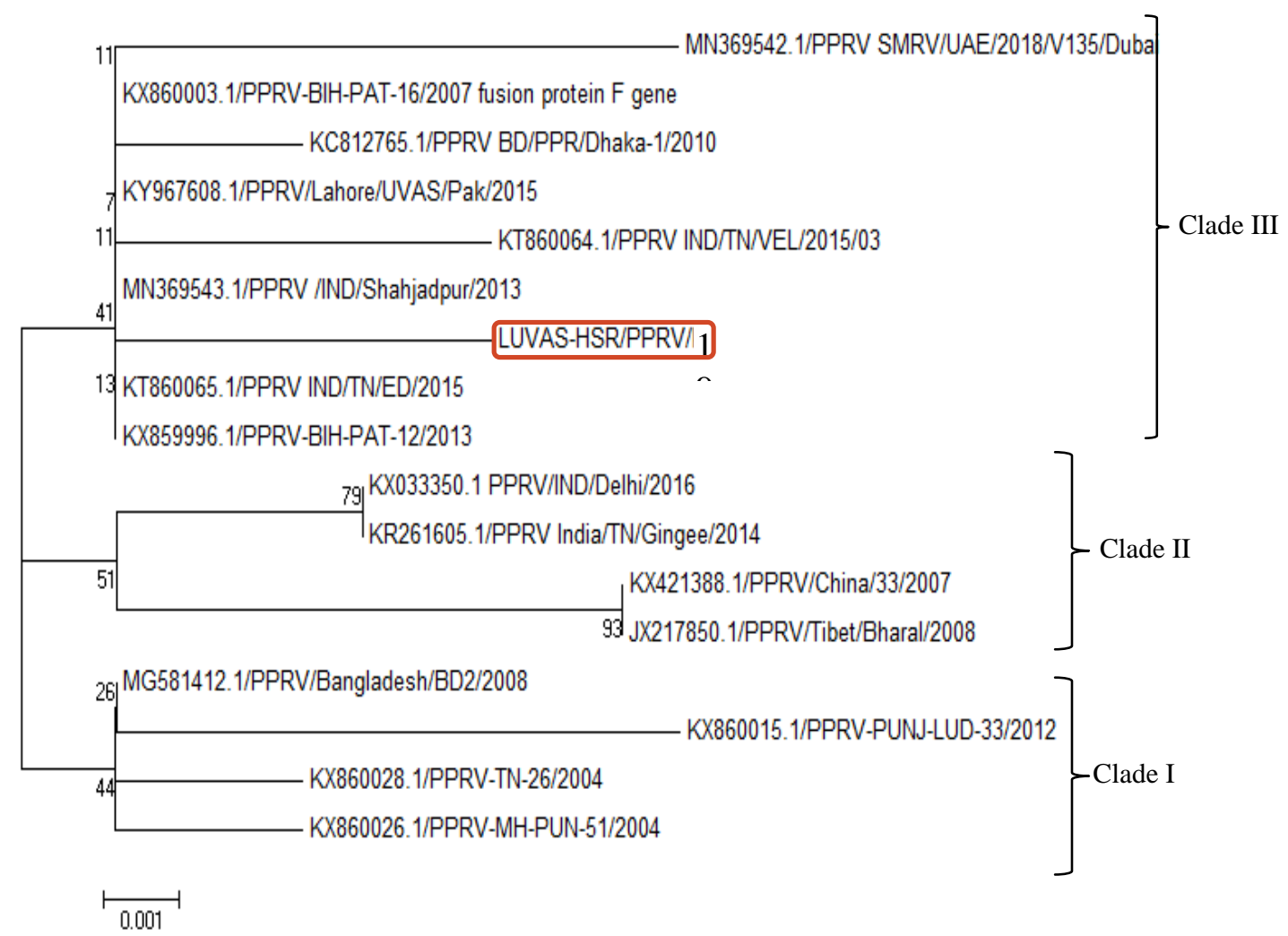

Among them, the nucleocapsid protein (NP) is the major viral protein. It has been the target for developing diagnostic tests that can be used to identify PPRV (Couacy-Hymann et al., 2002). The results of the present study are in accordance with study conducted Kerur et al., (2008) who reported $\mathrm{N}$ gene primers are more sensitive than F-gene based primers. The evident reason for higher sensitivity of the $\mathrm{N}$ gene based primers than $\mathrm{F}$ gene based primers can be attributed to the fact that $\mathrm{N}$ gene are most abundant transcripts of the virus and is the first protein to be produced, (Ghosh et al., 1995) thus making $\mathrm{N}$ gene more suitable target for improving the sensitivity of RT-PCR for detection of PPRV from clinical samples. The results are also in agreement with those of Mahajan et al., (2014) and Manar et al., (2017) who stated that $\mathrm{F}$ gene primers could give false negative results and suggested that $F$ gene primers could be easily replaced by the highly sensitive and specific $\mathrm{N}$ gene primers for the detection of PPRV nucleic acid.

\section{Phylogenetic analysis}

The phylogenetic tree (Fig. 2) based on the 351 bp sequence of $\mathrm{N}$ gene clustered all the PPRVs of India including those from the present study, isolates of turkey, an isolate of Pakistan and Iran into a separate branch from Nigerian isolate. While the phylogenetic analysis (Fig. 3) based on the 447 bp F gene sequences outrooted the Nigerian isolate, while the Turkey and Indian isolates were grouped into two clusters, although with low bootstrap values. The inferred phylogenetic relationship among the PPRV strains taken in this study vis-a-vis other PPRVs sequence showed that the PPRV of this study belonged to PPRV lineage IV (Figs. $2 \& 3$ ). 


\section{References}

Abu-Elzein, E.M., M.M. Hassanien, A.I. Alfaleq, M.A. Abd-Elhadi and F.M. Housawi (1990). Isolation of ppr virus from goats in saudi arabia. Vet. Rec.127: 309-310.

Bailey, D., Banyard, A., Dash, P., Ozkul, A., Barrett, T. (2005). Full genome sequence of peste des petits ruminants virus, a member of the Morbillivirus genus. Virus Res. 110: 119- 124.

Balamurugan, V., Sen, A., Saravanan, P., Singh, R.P., Singh, R.K., Rasool, T.J., Bandyopadhyay, S.K. (2006). One-step multiplex RT-PCR assay for the detection of peste des petits ruminants virus in clinical samples. Vet. Res. Commun., 30: 655-666

Barrett, T.; Banyard, A. C. and Diallo, A. (2005). Molecular Biology of the Morbilliviruses. Virus plagues of large and small ruminants. Elsevier, Amsterdam, Netherlands, pp: 31-67.

Couacy-Hymann E, Roger F, Hurard C, Guillou JP, Libeau G, Diallo A (2002). Rapid and sensitive detection of peste des petits ruminants virus by a polymerase chain reaction assay. Journal of Virological Methods, 100: 17-25.

Dhar, B., P. Sreenivasa, T. Barrett, M. Corteyn, R. P. Singh and S. K. Bandyopadhyay (2002). Recent epidemiology of peste des petits ruminants virus (PPRV). Vet. Microbiol., 88(2): 153-159.

Forsyth, M.A, and Barrett, T. (1995). Evaluation of polymerase chain reaction for the detection and characterisation of rinderpest and peste de petit ruminants viruses for epidemiological studies. Virus Res., 39, 151-163.

Ghosh, A., V. D. Joshi, M. S. Shaila (1995): Characterization of an in vitro transcription system from rinderpest virus. Vet. Microbiol. 44: 165-173.

Kerur, N., M. K. Jhala, C. G. Joshi (2008): Genetic characterization of Indian peste despetits ruminants virus (PPRV) by sequencing and phylogenetic analysis of fusion protein and nucleoprotein gene segments. Res. Vet. Sci. 85, 176-183.

Mahajan, S., R. Agrawal, M. Kumar, A. Mohan, N. Pande (2014). Comparative evaluation of different $\mathrm{F}$ and $\mathrm{N}$ gene based reverse transcription polymerase chain reaction for molecular detection of peste des petits ruminants virus from clinical samples. Vet. arhiv 84, 485-492.

Manar et al., (2017): Some molecular assays used for identity of Peste des Petits Ruminants (PPR) vaccines. Journal of Virological Sciences, Vol. 1: 155-162.

Saitou N and Nei M. (1987). The neighbourjoining method - a new method for reconstructing phylogenetic tree. Molecular Biology and Evolution.4 (4): 406-42.

Shaila M S, Purushothaman V, Bhavasar D, Venugopal K, Venkatesan RA (1989). Peste des petits ruminants of sheep in India. Veterinary Record, 125: 602.

Taylor WP. The distribution and epidemiology of PPR. Preventive Veterinary Medicine. 1984; 2:157-166.

Thompson, J.D., Higgins, D.G., and Gibson, T.J. (1994) CLUSTAL W: Improving the sensitivity of progressive multiple sequence alignment through sequence weighting, position-specific gap penalties and weight matrix choice. Nucleic Acids Res. 22: 4673-4680.

Zahur, A. B., A. Ullah, M. Hussain, H. Irshad, A. Hameed, M. Jahangir and M. S. Farooq (2011). Seroepidemiology of peste des petits ruminants (PPR) in pakistan. Prev.Vet. Med.102: 87-92.

\section{How to cite this article:}

Vandna Bhanot, Aman Kumar and Naresh Jindal. 2020. Detection and Molecular Characterization of Peste Des Petits Ruminants Virus from Goat Flocks in Ambala, Haryana. Int.J.Curr.Microbiol.App.Sci. 9(09): 522526. doi: https://doi.org/10.20546/ijcmas.2020.909.066 